\title{
Prevalence and Associated Risk Factors of Porcine Echinococcosis at the Ivorian Pig Slaughter Company (SIVAC), Yopougon Abidjan: A Cross Sectional Study
}

\author{
Touré Lisette1, Koné Naférima1, Toure Alassane², Emmanuel K. Mebourou ${ }^{3}$, Senin C. B. Valery ${ }^{4}$, \\ Sevidzem S. Lendzele5 ${ }^{*}$, Mavoungou J. François' ${ }^{6}$, Acapovi-Yao G. Lydie1 \\ ${ }^{1}$ UFR Biosciences, Université Félix Houphouët-Boigny, Abidjan, Côte d'Ivoire \\ ${ }^{2}$ Laboratoire National d'Appui au Développement Agricole, Laboratoire Central Vétérinaire de Bingerville, Bingerville, Côte d’Ivoire \\ ${ }^{3}$ Département des Sciences de la Vie, Faculté de Sciences, Université de Bangui, Bangui, République de Centrafrique \\ ${ }^{4}$ Département Hygiène et Santé Animale, Société Ivoirienne d'Abattage et de Charcuterie, Abidjan, Côte d'Ivoire \\ ${ }^{5}$ Laboratoire d'Ecologie Vectorielle (LEV-IRET), Ecole Doctorale des Grandes Ecoles (EDGE), Libreville, Gabon \\ ${ }^{6}$ Institut de Recherche en Ecologie Tropicale (IRET-CENAREST), Libreville, Gabon \\ Email: *seviddzem.lendze@gmail.com
}

How to cite this paper: Lisette, T., Naférima, K., Alassane, T., Mebourou, E.K., Valery, S.C.B., Lendzele, S.S., François, M.J. and Lydie, A.-Y.G. (2020) Prevalence and Associated Risk Factors of Porcine Echinococcosis at the Ivorian Pig Slaughter Company (SIVAC), Yopougon Abidjan: A Cross Sectional Study. Journal of Biosciences and Medicines, 8, 1-8.

https://doi.org/10.4236/jbm.2020.811001

Received: September 18, 2020

Accepted: November 3, 2020

Published: November 6, 2020

Copyright ( 2020 by author(s) and Scientific Research Publishing Inc. This work is licensed under the Creative Commons Attribution International License (CC BY 4.0).

http://creativecommons.org/licenses/by/4.0/ (c) (i) Open Access

\begin{abstract}
Background: Parasitic diseases are threat to the development of Ivorian Pig industry. Zoonotic diseases such as Echinococcosis have a significant impact on animal health and production. Little is known about Echinococcosis in Côte d'Ivoire. Aim: For these reasons, a cross section study was conducted at SIVAC in Yopougon, on pigs (Sus scrofa domesticus), in order to determine the prevalence and associated risk factors of Echinococcosis. Method: Paraclinical examinations of pig organs (kidneys, lungs, and liver) were conducted from $5^{\text {th }}$ September to $30^{\text {th }}$ December 2019 in order to report infection with this parasite. Results: Out of the 2425 slaughtered pigs, 63 of them were Echinococcosis positive, resulting in overall infection prevalence of $2.6 \%$ (95\% CI: $1.9 \%-3.22 \%)$. The kidneys (2.35\%) were most infected, followed by lungs $(0.21 \%)$, and liver $(0.04 \%)$. Recommendations: A more in-depth study on the molecular epidemiology of Echinococcosis in the different regions of Côte d'Ivoire is underway. Also, capacity building of community livestock actors (Veterinarians, health inspectors, breeders and butchers) and sensitization of the population on this disease is necessary in order to improve its diagnosis at the abattoir level and to set up strategies to combat it.
\end{abstract}

\section{Keywords}

Echinococcosis, Prevalence, Pig, SIVAC, Abidjan 


\section{Introduction}

Echinococcosis is a metacestodosis, infectious, inoculable, non-contagious in nature and common in humans and domestic animals. It is caused by the presence and development in the various organs and tissues (especially the liver and lungs) of an echinococcal-like larvae. It is a flat and segmented worm. Echinococcus species parasitizes certain canine mammals, mainly dogs [1].

Humans are accidentally an intermediate host and in this case, it is a fatal zoonosis if the management of the patient is late or poorly conducted. It has a significant impact on animal and human health where it causes approximately 19,300 deaths and 871,000 disability per year worldwide [2]. The annual costs attributable to this disease in terms of treatment and lots of animal to death stands at 3 billion US dollars (US\$).

This zoonosis is present in all regions of the world and hampers livestock farming [3]. Echinococcosis is subject of special surveillance by the health authorities in the Maghreb countries, eastern Africa and South Africa [4]. In West Africa, this zoonosis is still poorly understood [5]. In Côte d'Ivoire, few studies have been carried out on echinococcosis. However, the data available at the abattoir level indicates the presence of this disease in cattle, small ruminants, and pigs. These animals are carriers of hydatid cysts and demands that such organs should not be consumed by the public. The harmful impact of Echinococcosis on pig farming and human health as well as the lack of information on the prevailing species in Côte d'Ivoire, were the reasons that triggered the setting up of this study. The main objective is to assess the echinococcosis situation in pigs in Abidjan.

\section{Materials and Methods}

\subsection{Study Area and Period}

This study was carried out at SIVAC, located in the commune of Yopougon $\left(5^{\circ} 20^{\prime}\right.$ North and $4^{\circ} 00^{\prime}$ West). The commune of Yopougon is located in the southwestern part of the District of Abidjan in Côte d'Ivoire. To detect the presence of this disease in pigs, they were inspected by veterinarians before slaughter. This modern industrial abattoir deals only with pigs. It receives pigs from farms in the district of Abidjan and has a slaughter capacity of 24 animals per day. This study was conducted from September to December 2019. The breeds of pigs slaughtered in SIVAC during the study period consisted of Landrace (LR), Piétrain (Pi), Large White (LW) and Duroc (D), (Figure 1).

\subsection{Sampling Approach}

This study included all the pigs slaughtered during the survey with sampling effort of 2425 pigs inspected in 122 days.

\section{Inspection of Organs to Identify Echinococcosis Cysts}

Visual inspection and by palpation and/or incision at SIVAC was conducted by a well trained Veterinarian. Organs such as heart, kidneys, lungs and liver were 
carefully inspected for possible cysts, racemous vesicles forming multiple alveoli within a necro-fibrous focus, or lesions that may suggest echinococcosis [6] [7] (Figure 2).

\subsection{Data Analysis}

The R software (version 3.6.1) was used for statistical analysis. Prevalence and risk factors such as sex, animal breed, breeding system, locality and age were compared using the Chi-square test. The Generalised Linear Model (GLM) with Poisson family error distribution was used to analyze the influence of these risk factors on the carcass weight of the animals. The uniform distribution test was used to test the consistency of risk for developing echinococcosis in localities with statistically analysable data. A linear model was used to test the correlation between carcass weight and prevalence. All statistical tests were kept at $\mathrm{p}<0.05$ significance level.

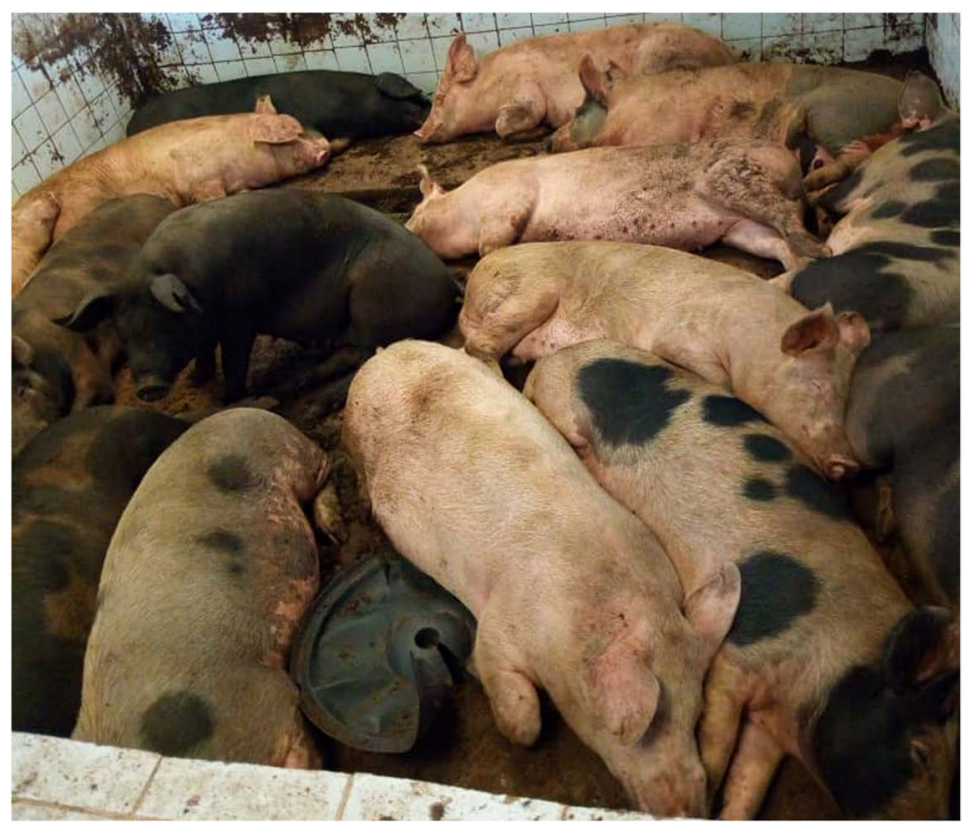

Figure 1. Pigs of different breeds kept for slaughtering at SIVAC.
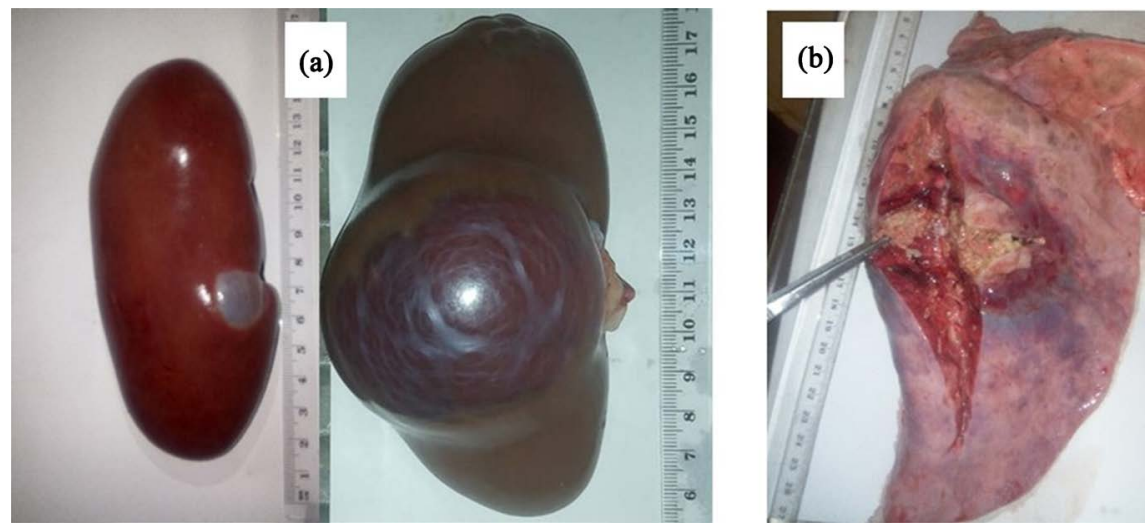

Figure 2. Some infected organs: (a) Kidneys; (b) Liver. 


\section{Results}

\subsection{Prevalence of Porcine Echinococcosis}

Out of the 2425 pigs inspected, 63 Echinococcus cysts were identified with overall infection prevalence of $2.60 \%$ (95\% CI: $1.97 \%-3.22 \%$ ).

\subsection{Prevalence of Porcine Echinococcosis with Age}

A superior infection prevalence of porcine echinococcosis was found in 8 months old pigs. However, statistically significant differences $(\mathrm{P}=0.0048)$ in prevalence rates occured in 8 months old pigs and the other age cohorts (Table 1).

\subsection{Prevalence of Porcine Echinococcosis with Sex}

Based on sex, females had a superior infection rate compared to their male counterparts with a statistically significant difference $(\mathrm{P}=0.0006)$ (Table 2$)$.

\subsection{Prevalence of Porcine Echinococcosis with Breed}

Regarding the breed of pigs, the Piétrain recorded the highest infection prevalence (Table 2$)$. There was a statistically significant difference $(\mathrm{P}<0.0001)$ in the prevalence of echinococcosis with breed.

\subsection{Prevalence with Husbandry System}

Pigs reared in the traditional husbandry system recorded the highest infection prevalence than those reared in other systems. A statistically significant difference $(\mathrm{P}=0.003)$ was recorded with prevalence of porcine echinococcosis and husbandry system (Table 2).

\subsection{Prevalence with Origin (Locality) of Animals}

A superior infection prevalence of porcine echinococcosis was recorded at Adzope. There was no statistically significant difference $(\mathrm{P}=0.86)$ in prevalence

Table 1. Prevalence of echinococcosis cyst with age of pigs.

\begin{tabular}{cccc}
\hline Age (months) & Number & Positive case & Prevalence (\%) \\
\hline 6 & 12 & 04 & 0.16 \\
7 & 136 & 03 & 0.12 \\
8 & 2253 & 41 & 1.69 \\
9 & 11 & 02 & 0.10 \\
10 & 09 & 09 & 0.37 \\
12 & 01 & 01 & 0.04 \\
17 & 01 & 01 & 0.04 \\
24 & 01 & 01 & 0.04 \\
26 & 01 & 01 & 0.04 \\
Total & 2425 & 63 & 2.60 \\
\hline
\end{tabular}


with locality (origin) (Table 2).

\subsection{Porcine Echinococcosis Prevalence and Organ}

We noticed that most of the infections were associated with kidneys, followed by the lungs and liver (Table 3).

\subsection{Correlation between Weight of Carcasses and Prevalence of Echinococcosis}

From the correlation analysis conducted between weight of pig and prevalence of echinococcosis, a strong, positive and significant correlation $\left(\mathrm{p}=0.037 ; \mathrm{R}^{2}=\right.$ 0.9 ) was recorded (Figure 3 ).

\section{Discussion}

The overall prevalence of Echinococcosis in pigs slaughtered at SIVAC was $2.6 \%$. This prevalence is higher than that obtained by Acapovi et al. [7] at the Port-Bouët slaughterhouse during a retrospective study in cattle. This difference

Table 2. Prevalence of Echinococcosis with sex, breed, husbandry system and locality.

\begin{tabular}{|c|c|c|c|c|c|}
\hline Risk factors & Variable & Number & Positive cases & Prevalence (\%) & p-value \\
\hline \multirow[t]{2}{*}{ Sex } & Male & 1714 & 33 & 1.93 & 0.0006 \\
\hline & Female & 648 & 30 & 4.63 & \\
\hline \multirow[t]{4}{*}{ Breed } & Duroc & 83 & 0 & 0.00 & $<0.0001$ \\
\hline & Large White & 2156 & 48 & 2.23 & \\
\hline & Landrace & 156 & 12 & 7.69 & \\
\hline & Piétrain & 30 & 3 & 10.00 & \\
\hline \multirow[t]{3}{*}{ Husbandry system } & Intensive & 1762 & 39 & 2.21 & 0.003 \\
\hline & Semi-intensive & 526 & 15 & 2.85 & \\
\hline & Traditional & 137 & 9 & 6.57 & \\
\hline \multirow[t]{5}{*}{ Locality } & Petit-Akoupe & 283 & 6 & 2.12 & 0.86 \\
\hline & Adzope & 109 & 5 & 4.59 & \\
\hline & Bingerville & 1164 & 29 & 2.49 & \\
\hline & Bouafle & 139 & 5 & 3.6 & \\
\hline & Taabo & 191 & 5 & 2.62 & \\
\hline
\end{tabular}

Table 3. Porcine echinococcosis prevalence with organ.

\begin{tabular}{ccc}
\hline Organ & Number infected/Number slaughtered & Prevalence (\%) \\
\hline Liver & $1 / 2425$ & 0.04 \\
Lungs & $5 / 2425$ & 0.21 \\
Kidney & $57 / 2425$ & 2.35 \\
Total & $63 / 2425$ & 2.6 \\
\hline
\end{tabular}




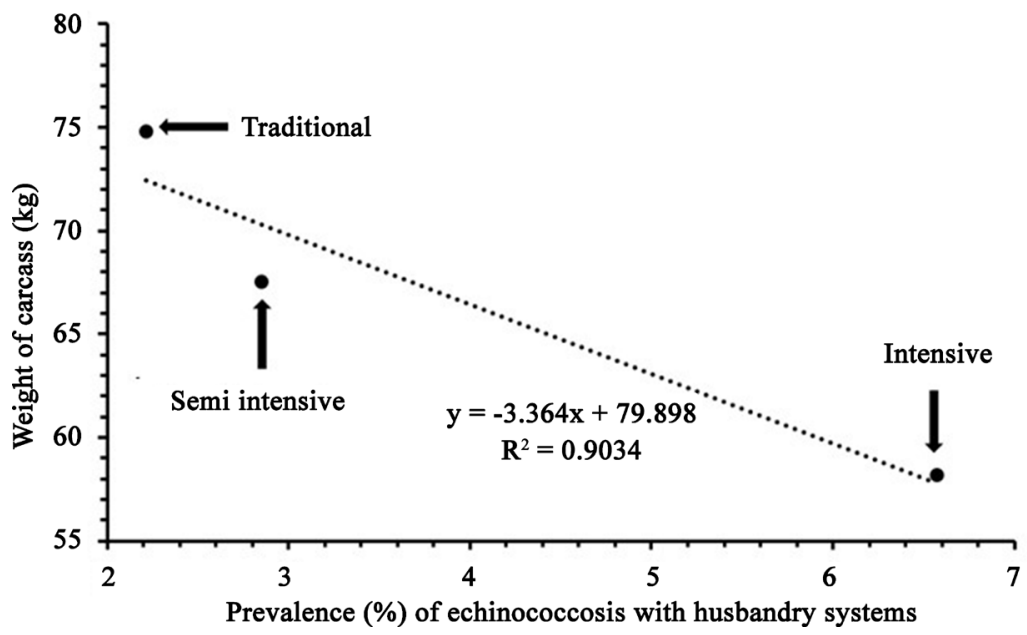

Figure 3. Correlation plot between weight of carcasses and porcine echinococcosis prevalence.

could be explained by the fact that the number of cattle slaughtered is 6 times higher than the number of pigs. A study carried out at the Haute-Corse slaughterhouse on 2527 pigs, 5970 sheep, 2431 cattle and 1860 goats, resulted in prevalence of $5.9 \%$, with pigs as the only infected animal species [8]. The prevalence from this study is superior to that obtained in SIVAC but shows once again the vulnerability of pigs to echinococcosis. The lower prevalence in the present study at SIVAC could also be due to the sample size. The number of animals slaughtered at SIVAC is lower than that at the Haute-Corse slaughterhouse in France. In addition, the low prevalence of echinococcosis in our study coud be related to the diagnostic approach which was clinical diagnosis with low sensitivity. However, the use of molecular (PCR) and serological (ELISA) tools which are more sensitive would have led to the detection of higher cases as well as the prevailing species compared to clinical diagnosis [9] [10] [11]. One of the main limitation of this study is the use of clinical diagnositic approach to identify the cyst of echinococossis rather than confirming the presence of the disease using more sensitive screening approaches such as ELISA and PCR.

The organs detected with echinococcosis infection included the kidneys, lungs and liver as already reported by Acapovi et al. [7] who also established that for large and small ruminants, the kidney was the most infected organ.

The prevalence of echinococcosis with breed indicated that Pietrain recorded highest prevalence rate. This high prevalence could be explained by the very low number of Pietrain pigs compared to other breeds.

Based on porcine echinococcosis prevalence with sex, it was noticed that male pigs had a higher prevalence than their female counterparts. These results are contrary to those obtained from a study conducted on ruminants in north east Morocco by El Brebri et al. [12]. According to them, females are more vulnerable to echinococcosis infection than males [13]. This difference could also be explained by the lower number of female animals examined in this study.

The traditional breeding system recorded highest prevalence (6.57\%). This 
highest prevalence could be due to the fact that in the traditional breeding system, animals are left to feed in all sorts of environments that predisposes them to infections [14] [15]. Moreover, in semi-intensive system, the animals are fed with kitchen remains or agricultural waste that could be soiled with parasite eggs.

The results of this present study show that older animals had a higher prevalence rate of echinococcosis. This finding is similar to that reported in several studies carried out in Morocco, Algeria, Tunisia, and Ethiopia [12] [16] [17] [18] [19]. According to these authors, the prevalence of echinococcosis increase with age. This correlation is thought to be caused by the wanning immune system of animals with age. Also, Echinococcus would prefer to develop in older animals with immunosuppressed system. Indeed, the infection period of this parasite is between 4 and 13 months, which makes it difficult for diagnosis in younger host.

The prevalence obtained at SIVAC could be explained by the fact that the pigs come from breeding areas where the environment, habitat, feeding grounds are infested by echinococcal tapeworm eggs such as those coming from Adzope locality that recorded the highest infection prevalence.

\section{Conclusion}

This abattoir study resulted in porcine echinococcosis prevalence of $2.6 \%$. Kidneys recorded the highest infection prevalence with hydatid cysts. Host related risk factors such as age, sex, breed and not locality significantly affected the prevalence of echinococcosis in pigs. There was a strong and significant association between weight of pigs and porcine echinococcosis prevalence.

\section{Acknowledgements}

Authors are grateful to SIVAC and LANADA for their technical and material support throughout this study.

\section{Conflicts of Interest}

The authors declare no conflicts of interest regarding the publication of this paper.

\section{References}

[1] Zinelabiddine, L. (2015) Contribution à l'étude de la fréquence et la fertilité des kystes hydatiques chez les ovins dans la région de Batna. Thèse de Doctorat de l’Université El Hadj Lakhdar, Batna, Algérie, 103 p.

[2] WHO (2015) Aide-Mémoire sur l'échinococcose (mis à jour en mai 2019). Revue Épidémiologique Hebdomadaire, 574-580.

[3] Develoux, M. (1996) L'hydatidose en Afrique: Aspect épidémiologique. Médecine Tropicale, 56, 177-183.

[4] Majorowski, M.M., Carabin, H., Kilani, M., et al. (2005) Echinococcosis in Tunisia: A Cost Analysis. Transactions Royal Society of Tropical Medicine and Hygiene, 99, 268-278. https://doi.org/10.1016/j.trstmh.2004.06.011 
[5] Bizuwork, A., Kebede, N., Tibat, T., et al. (2012) Occurrences and Financial Significance of Bovine Cystic Echinococcosis in Southern Wollo, Northeastern Ethiopia. Journal Veterinary Medicine and Animal Health, 5, 51-56.

[6] OIE (2008) Echinococcose ou hydatidose. Fiches d'information générale sur les maladies. Paris, 6 p.

[7] Acapovi, G.L.Y., Beugré, J.M.V., Yapi, C., et al. (2019) Analysis of the Situation of Bovine Cystic Echinococcosis at the Port-Bouët Abattoir: A Retrospective Study from 2008-2015. International Journal Biology Chemical Sciences, 13, 1527-1533. https://doi.org/10.4314/ijbcs.v13i3.25

[8] Umhang, G., Hormaz, V., Peytavin, C., et al. (2012) Epidémiosurveillance d'Echinococcus granulosus à l'abattoir: Résultats du plan de surveillance 2012. Bulletin épidémiologique, santé animale et alimentation, 62, 8-12.

[9] Boue, F., Ikhlass, E., Vanessa, H., et al. (2017) Use of FTA Card Methodology for Sampling and Molecular Characterization of Echinococcus granulosus Sensu Lato in Africa. Experimental Parasitology, 173, 29-33. https://doi.org/10.1016/j.exppara.2016.12.016

[10] Tamarozzi, F., Covini, I., Mariconti, M., et al. (2016) Comparison of the Diagnostic Accuracy of Three Rapid Tests for the Serodiagnosis of Hepatic Cystic Echinococcosis in Humans. PLoS Neglected Tropical Disease, 10, e0004444. https://doi.org/10.1371/journal.pntd.0004444

[11] Monteiro, D.U., Sônia de Avila, B., Alexandre, A.T., et al. (2015) Echinococcus granulosus Sensu Lato and Taenia hydatigena in Pig in Southern Brazil. Brazilian Journal of Veterinary Parasitology, 24, 227-229. https://doi.org/10.1590/S1984-29612015026OI

[12] El Berbri, I., Petavy, A.F., Umhang, G., et al. (2015) Epidemiological Investigations on Cystic Echinococcosis in North-West (Sidi Kacem Province) Morocco: Infection in Ruminants. Advances in Epidemiology, 2015, Article ID: 104025. https://doi.org/10.1155/2015/104025

[13] Ohiolei, J.A., Yan, H.B., Li, L., et al. (2020) Review of Cystic Echinococcosis in Nigeria: A Story of Neglect. Acta Parasitologica, 65, 1-10. https://doi.org/10.2478/s11686-019-00124-x

[14] Abah, S., Njan Nloga, A.M., Zoli, A.P., et al. (2017) Commercial Acaricides in PourOn Formulation React Differently in Reducing Tick Numbers on Cattle in Extensive and Intensive Management Systems in Bockle, North Cameroon. Direct Research Journal in Agricultural and Food Science, 5, 232-238.

[15] Mfewou, A. and Lendzele, S.S. (2018) Urban-Pig Farming: Easy Gain and Danger to the Environment (Yaounde-Cameroon). Agriculture Studies, 2, 190-198.

[16] Kebede, N., Mitiku, A., Tilahun, G., et al. (2009) Hydatidosis in Slaughtered Animals in Bahir Dar Abattoir, North-Western Ethiopia. Tropical Animal Health and Production, 41, 43-50. https://doi.org/10.1007/s11250-008-9152-3

[17] Hamrat, K., Achour, Y., Yacin, G., et al. (2011) Epidemiological Study of Hydatidosis in the Steppe Regions of Djelfa, Algeria. Scientia Parasitologica, 12, 177-183.

[18] Kouidri, F.B., Benchaib, K.F., Boulkaboul, A., et al. (2012) Prevalence, Fertility and Viability of Cystic Echinococcosis in Sheep and Cattle of Algeria. Bulgarian Journal of Veterinary Medicine, 15, 191-197.

[19] Lahmar, S., Trifi, M., Ben-Naceuretal, S., et al. (2013) Cysticechinococcosis in Slaughtered Domestic Ruminants from Tunisia. Journal of Helminthology, 87, 318325. https://doi.org/10.1017/S0022149X12000430 